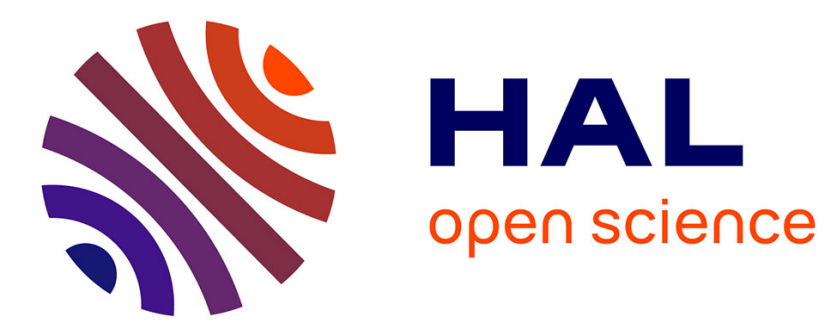

\title{
Metalated Porphyrins as versatile visible light and NIR photoinitiators of polymerization
}

Guillaume Noirbent, Yangyang Xu, Aude-Héloise Bonardi, Didier Gigmes, Jacques Lalevée, Frédéric Dumur

\section{- To cite this version:}

Guillaume Noirbent, Yangyang Xu, Aude-Héloise Bonardi, Didier Gigmes, Jacques Lalevée, et al.. Metalated Porphyrins as versatile visible light and NIR photoinitiators of polymerization. European Polymer Journal, 2020, 139, pp.110019. 10.1016/j.eurpolymj.2020.110019 hal-02941898

\author{
HAL Id: hal-02941898 \\ https://hal.science/hal-02941898
}

Submitted on 17 Sep 2020

HAL is a multi-disciplinary open access archive for the deposit and dissemination of scientific research documents, whether they are published or not. The documents may come from teaching and research institutions in France or abroad, or from public or private research centers.
L'archive ouverte pluridisciplinaire HAL, est destinée au dépôt et à la diffusion de documents scientifiques de niveau recherche, publiés ou non, émanant des établissements d'enseignement et de recherche français ou étrangers, des laboratoires publics ou privés. 
Metalated Porphyrins as versatile visible light and NIR photoinitiators of polymerization

Guillaume Noirbent ${ }^{1}$, Yangyang Xu ${ }^{2,3}$, Aude-Héloise Bonardi ${ }^{2,3}$, Didier Gigmes ${ }^{1}$, Jacques Lalevée ${ }^{2,3^{*}}$ and Frédéric Dumur ${ }^{{ }^{*}}$

${ }^{1}$ Aix Marseille Univ, CNRS, ICR UMR 7273, F-13397 Marseille, France.

${ }^{2}$ Institut de Science des Matériaux de Mulhouse, IS2M-UMR CNRS 7361, UHA, 15, rue Jean Starcky, Cedex 68057 Mulhouse, France.

${ }^{3}$ Université de Strasbourg, France.

E-mail: frederic.dumur@univ-amu.fr; jacques.lalevee@uha.fr

\section{Keywords:}

porphyrin; photoinitiator; NIR light; visible light; free radical polymerization; thermal initiator

\section{Abstract:}

A series of metalated porphyrins has been prepared and used as visible light photoinitiators of polymerization activable under low light intensity. Among the six metalated porphyrins examined in this work, five of them have never been reported in the literature and specifically designed to exhibit a good solubility in monomers. Three of the proposed structures were efficient @ 405nm but remarkably, despites their weak absorptions at 785 nm, efficient Near Infrared (NIR) polymerization profiles could also be obtained during the free radical polymerization of a methacrylate resin. To support the experimental observation of a polymerization process, a mechanism has been proposed based on combined photochemical and photothermal pathways.

\section{Introduction}

Polymer products are now everywhere in our daily life and these materials can advantageously replace the traditional materials such as steel, glass, wood, stone or concrete in numerous applications. ${ }^{[1-2]}$ Polymers benefit from numerous advantages such as being lightweight, rigid or flexible on demand and these materials can also display remarkable thermal, electrical or magnetic properties. As final advantages, polymers can also be recycled or reused after application of the appropriate treatment. ${ }^{[3-4]}$ Due to their widespread use, a great deal of 
efforts has been devoted to develop new routes to access to these polymeric materials. In this field, visible light photopolymerization has the capacity to replace the traditional UV photopolymerization still extensively used in industry. ${ }^{[5]}$ Indeed, UV polymerization is facing numerous drawbacks such as the requirements of using adequate precautions as an accidental exposure to UV light can cause severe eyes and skin damages. Parallel to this, expensive irradiation setups and high-energy consumption are associated with UV photopolymerization. In this context, visible light photopolymerization appears as a promising alternative as cheap and lightweight light sources such as light-emitting diodes (LEDs) can be advantageously used. ${ }^{[6-10]}$ Higher light penetration inside the photocurable resins can be also obtained, enabling to polymerize thick samples. ${ }^{[11]}$ Conversely, due to the limited light penetration with UV light, UV photopolymerization is restricted to the polymerization of thin samples. Considering that the light penetration is the key-parameter to polymerize thick samples, recently, NIR light photopolymerization has been the focus of numerous research efforts and structures such as squaraines, phthalocyanines, cyanines, Bodipys or negative photochroms such as the DonorAcceptor Stenhouse Adducts (DASA) have been examined for this purpose. ${ }^{[12-21]}$ However, there is a constant strive to find new structures activable in the near infrared region. At present, porphyrins have only been scarcely for NIR light polymerization despites their appropriate absorptions. ${ }^{[22-23]}$ Besides, a few examples of porphyrins used as visible photoinitiators can be cited. Notably, in 2015, an interesting report mentioning the use of Zn-porphyrins as photoredox catalysts for living radical polymerization in the 435-655 $\mathrm{nm}$ range was published by Boyer and coworkers.[24] But living radical polymerization could also be initiated with Co-based porphyrins or even chlorophyll, still in the visible range.[25-29] However, in these different works, photoinitiation in the near-infrared region has never been examined. Porphyrins can be easily found in Nature, mostly complexed with iron or magnesium cations. Among the most popular porphyrins, those that can be found in hemoglobins, myoglobins, cytochromes, and chlorophylls can be cited as the most relevant examples. ${ }^{[30]}$ In our previous works, we have 
shown that zinc tetraphenylporphyrin can be used in multicomponent initiating systems for both radical and cationic polymerization upon near UV or visible light (e.g. $405 \mathrm{~nm}) .{ }^{[31]}$ Therefore, in this work, a new series of metalloporphyrins has been examined as photoinitiators of polymerization and extended to longer wavelength polymerization (i.e. NIR light). Noticeably, among the six metalloporphyrins examined in this work, five of them have been designed with long aliphatic chains to improve the solubility in monomers. Considering that a sufficient solubility of photoinitiators in the monomer is primordial to efficiently initiate a polymerization process, ${ }^{[32,33]}$ several metal-free porphyrins have been rapidly discarded for metalation due to the solubility issues. As a result of this, three porphyrins were metalated with various metal cations such as $\mathrm{Pd}^{2+}, \mathrm{Cu}^{2+}, \mathrm{Zn}^{2+}, \mathrm{Fe}^{2+}$. Among the selected set of metalloporphyrins, the free radical polymerization (FRP) of a methacrylate resin (Mix-MA) could only be efficiently promoted at $405 \mathrm{~nm}$ and $785 \mathrm{~nm}$ under air (i.e. in oxygen inhibition conditions) with three of the synthesized porphyrins (See Figure 1). At $405 \mathrm{~nm}$, a pure photochemical approach can be used to generate the initiating radicals in presence of metalloporphyrins, iodonium salt and phosphine (4-dppba). Whereas for polymerization upon NIR light $(785 \mathrm{~nm})$, the addition of a thermal initiator was required for a combined photochemical/photothermal approach. Indeed, the polymerization of acrylates and methacrylates is also a highly exothermic reaction as it consists in converting double bonds to single bond. As a consequence of this, if a thermal initiator is introduced into the photocurable resin, the heat released during the polymerization process can promote the decomposition of the thermal photoinitiator if a sufficient temperature is reached by the reaction media. A heater behavior for porphyrins upon NIR light is also highlighted. As a result of this, a second source of radicals can be generated in situ, improving the monomer conversion. In this study, incorporation of a well-known thermal initiator, namely BlocBuilder MA which a thermosensitive alkoxyamine, ${ }^{[34-36]}$ has been introduced in the resins so that a significant enhancement of both the polymerization speed as well as the final monomer conversion could be detected. 


\section{Materials and methods}

\subsection{Materials}

The three metalloporphyrins investigated in this work were synthesized according to procedures depicted below and their corresponding chemical structures are presented in Figure 1. Di-tert-butyl-diphenyl iodonium hexafluoro-phosphate (noted as Iod) was obtained from Lambson Ltd (UK) and 4-(diphenylphosphino) benzoic acid (4-dppba) was purchased from Tokyo Chemical Industry (TCI) Chemicals. Mix-Ma is a resin composed of three different monomers in a 33/33/33 (wt $\% / w t \% / w t \%)$ ratio, composed of HPMA (2-hydroxypropyl) methacrylate, 1,4-BDDMA (1,4-butanediol dimethacrylate) and UDMA (a urethane dimethacrylate). Mix-Ma has a low viscosity of 0.053 Pa. BlocBuilder MA was obtained from Arkema (See Figure 2). All the chemical compounds were selected with the highest purity available and used as received. For all the formulations mentioned in this work, weight percentages are related to the resin.

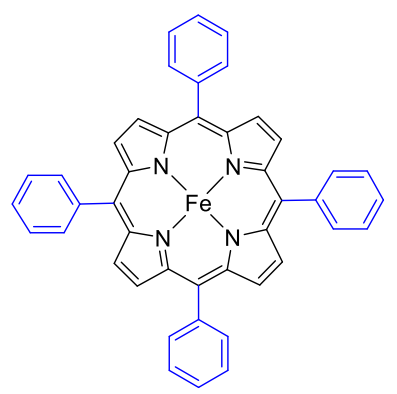

Fe-Porph_1

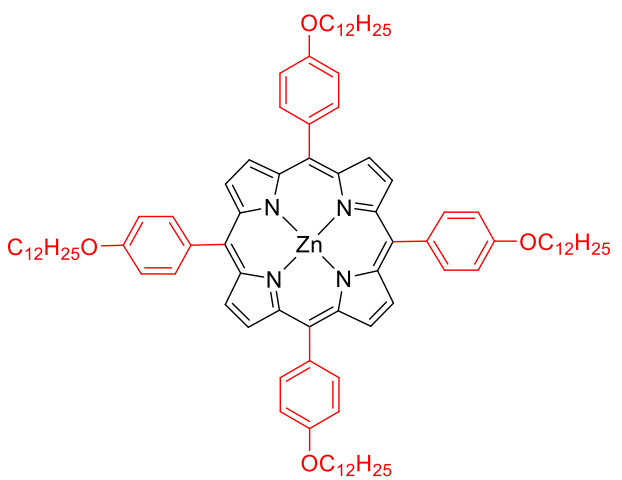

Zn-Porph_2

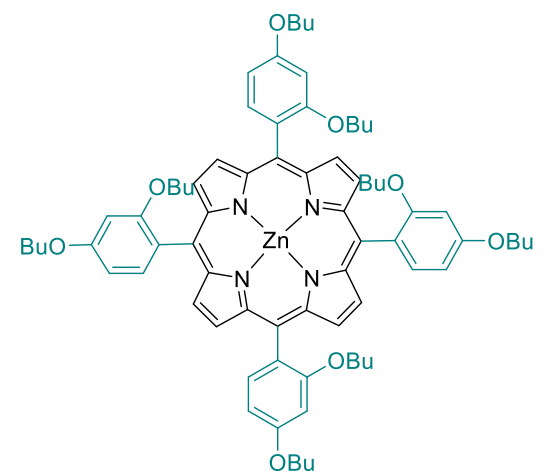

Zn-Porph_4

Figure 1. Chemical structures of metalloporphyrins used in this study.

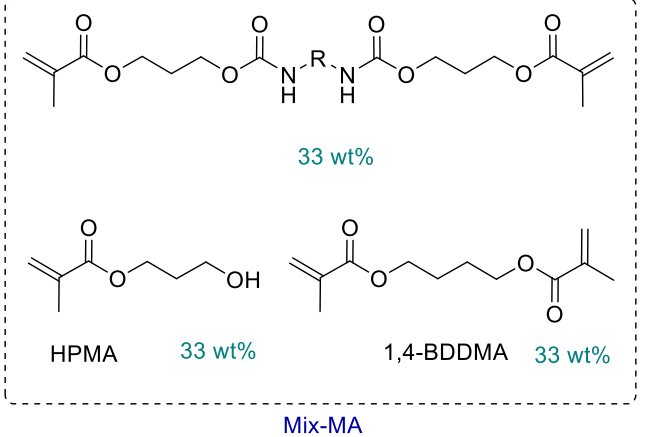

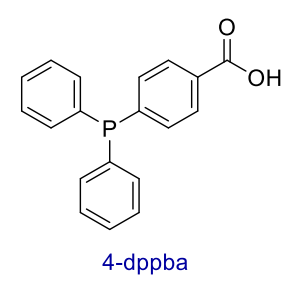
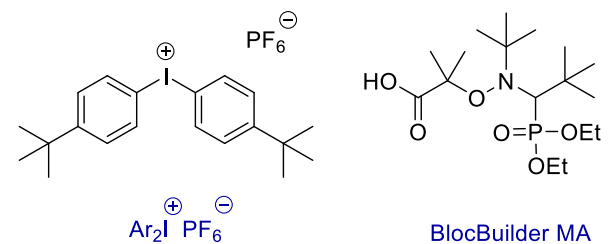

BlocBuilder MA 
Figure 2. Chemical structures of the different additives (4-dppba, Iod and BlocBuilder MA) and the monomer (Mix-MA).

\subsection{Sample preparation}

For the free radical polymerization, metallophorphyrins (photoinitiators), Iod (electron acceptor) and 4-dppba (electron donor) were successfully added into Mix-MA (0.1\%/3\%/2\%, $\mathrm{w} / \mathrm{w})$, and the weight percent of the three-component photoinitiating system was calculated from the monomer content. For the four component systems, the following composition was used, namely Porph/Iod/4-dppba/BlocBuilder $(0.1 \% / 3 \% / 2 \% / 2 \%$, w/w). Upon mechanical mixing at a rotation speed of $1500 \mathrm{rpm}$ with a SpeedMixer (DAC 150.1 FVZ-K) (FlackTek Inc., Landrum USA), homogeneous resins could be obtained, which were stored in dark environment at room temperature before irradiation.

\subsection{Irradiation source}

A Laser diode emitting at $785 \mathrm{~nm}$ (supplied by Changchun New Industries Optoelectronics Technology Co., Ltd) has been used and the incident light intensity at the surface of the sample was $2.5 \mathrm{~W} \cdot \mathrm{cm}^{-2}$.

\subsection{Real-time Fourier transform infrared spectroscopy}

For the free radical polymerization, the prepared photosensitive formulations were deposited into a $1.4 \mathrm{~mm}$ thick round mold or $25 \mu \mathrm{m}$ thin films. Evolution of the $\mathrm{C}=\mathrm{C}$ double bond content of Mix-MA was continuously followed using real time Fourier transform infrared spectroscopy (RT-FTIR, JASCO FTIR 4100 (JASCO, Tokyo Japan)) at about $6160 \mathrm{~cm}^{-1}$ and $1630 \mathrm{~cm}^{-1}$, respectively. The final conversion (FC) of the reactive groups at time $t$ during the photopolymerization was calculated using $\mathrm{FC}=\left(\mathrm{A}_{0}-\mathrm{A}_{\mathrm{t}}\right) / \mathrm{A}_{0} \times 100 \%$ (where $\mathrm{A}_{0}$ is the initial peak area of the functional groups before irradiation and $A_{t}$ is the peak area at irradiation time t). ${ }^{[37,38]}$ The set-up and procedure to follow polymerization upon NIR lights have been presented in $[15-17]$.

\subsection{Synthesis of the dyes}


All compounds were characterized using the procedures and equipments $\left({ }^{1} \mathrm{H}\right.$ and ${ }^{13} \mathrm{C}$ NMR, high resolution mass spectrometry (HRMS),...) reported elsewhere. ${ }^{[39]}$ 4Dodecylbenzaldehyde ${ }^{[40]}$, 2-dodecylbenzaldehyde ${ }^{[41]}$, 2,4-dibutoxybenzaldehyde ${ }^{[42]}$, 2butoxy-4-diethylaminobenzaldehyde ${ }^{[43]}$ and 9-hexyl-9H-carbazole-3-carbaldehyde [44], Porph_1 ${ }^{[45-49]}$, Porph_2 ${ }^{[50]}$, Porph_3 ${ }^{[51]}$, Porph_6 ${ }^{[52-54]}$, Porph_7 ${ }^{[55]}$, Porph_8 ${ }^{[56]}$, FePorph_1 ${ }^{[57]}$ were synthesized, as previously reported in the literature, without modification and in similar yields.

Synthesis of 5,10,15,20-tetrakis(2,4-dibutoxyphenyl)porphyrin Porph_4

To a $500 \mathrm{~mL}$ two-necked round-bottomed flask equipped with a water condenser, a mixture of 2,4-dibutoxybenzaldehyde $(25.0 \mathrm{~g}, 100 \mathrm{mmol}, \mathrm{M}=250.34 \mathrm{~g} / \mathrm{mol})$ in propionic acid $(400 \mathrm{~mL})$ was added under $\mathrm{N}_{2}$. The reaction solution was heated up to $130^{\circ} \mathrm{C}$ and then pyrrole $(6.7 \mathrm{~g}, 100$ mmol) was added. The mixture was stirred at $140^{\circ} \mathrm{C}$ for $2 \mathrm{~h}$. After cooling to room temperature, the dark violet precipitate was filtered off, washed with methanol several times and dried under vacuum $\left(7.74 \mathrm{~g}, 26 \%\right.$ yield). ${ }^{1} \mathrm{H}-\mathrm{NMR}\left(\mathrm{CDCl}_{3}\right) \delta: 8.80(8 \mathrm{H}, \mathrm{s}), 7.87(4 \mathrm{H}, \mathrm{m}), 6.89(4 \mathrm{H}, \mathrm{s}), 6.87$ (4H, m), $4.28(8 \mathrm{H}, \mathrm{m}), 3.86(8 \mathrm{H}, \mathrm{m}), 2.01(8 \mathrm{H}, \mathrm{m}), 1.66(8 \mathrm{H}, \mathrm{m}), 1.55-0.51(42 \mathrm{H}, \mathrm{m}),-2.60$ $(2 \mathrm{H}, \mathrm{s})$; Anal. Calc. for $\mathrm{C}_{76} \mathrm{H}_{94} \mathrm{~N}_{4} \mathrm{O}_{8}$ : C, 76.6; H, 7.9; O, 10.7; Found: C, 76.4; H, 7.7; O, $10.5 \%$; HRMS (ESI MS) m/z: theor: 1191.7144 found: $1191.7145[\mathrm{M}+\mathrm{H}]^{+}$detected).

Synthesis of 5,10,15,20-tetrakis(2-butoxy-4-diethylaminophenyl)porphyrin Porph_5

To a $500 \mathrm{~mL}$ two-necked round-bottomed flask equipped with a water condenser, a mixture of 2-butoxy-4-diethylaminobenzaldehyde (24.9 g, $100 \mathrm{mmol}, \mathrm{M}=249.35 \mathrm{~g} / \mathrm{mol})$ in propionic acid (400 mL) was added under $\mathrm{N}_{2}$. The reaction solution was heated up to $130^{\circ} \mathrm{C}$ and then pyrrole $(6.7 \mathrm{~g}, 100 \mathrm{mmol})$ was added. The mixture was stirred at $140^{\circ} \mathrm{C}$ for $2 \mathrm{~h}$. After cooling to room temperature, the dark violet precipitate was filtered off, washed with methanol several times and dried under vacuum $(6.24 \mathrm{~g}, 21 \%$ yield $) .{ }^{1} \mathrm{H}-\mathrm{NMR}\left(\mathrm{CDCl}_{3}\right) \delta: 8.82(8 \mathrm{H}, \mathrm{s}), 7.82(4 \mathrm{H}, \mathrm{m})$, 
$6.83(4 \mathrm{H}, \mathrm{s}), 6.81(4 \mathrm{H}, \mathrm{m}), 4.02(8 \mathrm{H}, \mathrm{m}), 3.42(16 \mathrm{H}, \mathrm{m}), 1.79(8 \mathrm{H}, \mathrm{m}), 1.53(8 \mathrm{H}, \mathrm{m}), 1.19(24 \mathrm{H}$, m), $0.98(12 \mathrm{H}, \mathrm{m}),-2.63(2 \mathrm{H}, \mathrm{s})$; Anal. Calc. for $\mathrm{C}_{76} \mathrm{H}_{98} \mathrm{~N}_{8} \mathrm{O}_{4}$ : C, 76.9; H, 8.3; O, 5.4; Found: C, 76.8; H, 8.5; O, $5.5 \%$; HRMS (ESI MS) m/z: theor: 1187.7784 found: $1187.7789[\mathrm{M}+\mathrm{H}]^{+}$ detected).

Synthesis of [5,10,15,20-Tetrakis(4-dodecyloxyphenyl)porphyrinate]Fe (II) Fe-Porph_2 To a solution of Porph_2 $(1.35 \mathrm{~g}, 1 \mathrm{mmol}, \mathrm{M}=1352.04 \mathrm{~g} / \mathrm{mol})$ in chloroform $(100 \mathrm{~mL})$ was added a solution of iron acetate $(173 \mathrm{mg}, 1 \mathrm{mmol}, \mathrm{M}=173.93 \mathrm{~g} / \mathrm{mol})$ in DMF (20 mL). The mixture was refluxed for $1 \mathrm{~h}$. After cooled to room temperature, the solvent was removed under reduced pressure. After washing by methanol, the crude was purified by column chromatography $\left(\mathrm{SiO}_{2}\right)$ using chloroform) as the eluent to yield [5,10,15,20-tetrakis(4dodecyloxyphenyl) porphyrinate]Fe(II) (913 mg, 65\% yield) as a purple powder. Anal. Calc. for $\mathrm{C}_{92} \mathrm{H}_{124} \mathrm{FeN}_{4} \mathrm{O}_{4}$ : C, 78.6; H, 8.9; O, 4.5; Found: C, 78.8; H, 8.8; O, 4.5 \%; HRMS (ESI MS) m/z: theor: 1404.8972 found: $1404.8974\left(\mathrm{M}^{+} \cdot\right.$ detected $)$.

Synthesis of [5,10,15,20-Tetrakis(4-dodecyloxyphenyl)porphyrinate]Zn (II) Zn-Porph_2 To a solution of Porph_2 (1.35 g, $1 \mathrm{mmol}, \mathrm{M}=1352.04 \mathrm{~g} / \mathrm{mol})$ in chloroform (100 mL) was added a solution of zinc acetate dihydrate $(0.25 \mathrm{~g}, 1 \mathrm{mmol}, \mathrm{M}=251.19 \mathrm{~g} / \mathrm{mol})$ in methanol (20 $\mathrm{mL}$ ). The mixture was refluxed for $1 \mathrm{~h}$. After cooled to room temperature, the solvent was removed under reduced pressure. After washing by methanol, the crude was purified by column chromatography $\left(\mathrm{SiO}_{2}\right)$ using chloroform) as the eluent to yield [5,10,15,20-tetrakis(4dodecyloxyphenyl) porphyrinate]Zn(II) $\left(764 \mathrm{mg}, 54 \%\right.$ yield) as a solid. ${ }^{1} \mathrm{H}-\mathrm{NMR}\left(\mathrm{CDCl}_{3}\right) \delta$ : $8.97(8 \mathrm{H}, \mathrm{s}), 8.11(8 \mathrm{H}, \mathrm{d}, \mathrm{J}=9 \mathrm{~Hz}), 7.27(8 \mathrm{H}, \mathrm{d}, \mathrm{J}=9 \mathrm{~Hz}), 4.26(8 \mathrm{H}, \mathrm{t}, \mathrm{J}=7 \mathrm{~Hz}), 1.99(8 \mathrm{H}$, quint, $\mathrm{J}=7 \mathrm{~Hz}), 1.63(8 \mathrm{H}$, quint, $\mathrm{J}=7 \mathrm{~Hz}), 1.25-1.52(\mathrm{~m}, 64 \mathrm{H}), 0.87(12 \mathrm{H}, \mathrm{t}, \mathrm{J}=7.0 \mathrm{~Hz})$; HRMS (ESI MS) m/z: theor: 1412.8914 found: $1412.8916\left(\mathrm{M}^{+\cdot}\right.$ detected). 
Synthesis of [5,10,15,20-Tetrakis(4-dodecyloxyphenyl)porphyrinate]Cu (II) Cu-Porph_2

To a solution of Porph_2 $(1.35 \mathrm{~g}, 1 \mathrm{mmol}, \mathrm{M}=1352.04 \mathrm{~g} / \mathrm{mol})$ in chloroform (100 mL) was added a solution of copper acetate hydrate $(0.18 \mathrm{~g}, 1 \mathrm{mmol}, \mathrm{M}=181.63 \mathrm{~g} / \mathrm{mol})$ in methanol (20 $\mathrm{mL}$ ). The mixture was refluxed for $1 \mathrm{~h}$. After cooled to room temperature, the solvent was removed under reduced pressure. After washing by methanol, the crude was purified by column chromatography $\left(\mathrm{SiO}_{2}\right)$ using chloroform) as the eluent to yield [5,10,15,20-tetrakis(4dodecyloxyphenyl) porphyrinate]Cu(II) (1.34 g, 95\% yield) as a solid. Anal. Calc. for $\mathrm{C}_{92} \mathrm{H}_{124} \mathrm{FeN}_{4} \mathrm{O}_{4}: \mathrm{C}, 78.2 ; \mathrm{H}, 8.8 ; \mathrm{O}, 4.5$; Found: C, 78.1; H, 8.9; O, 4.6 \%; HRMS (ESI MS) m/z: theor: 1411.8919 found: $1411.8924\left(\mathrm{M}^{+} \cdot\right.$ detected $)$.

Synthesis of [5,10,15,20-Tetrakis(4-dodecyloxyphenyl)porphyrinate]Pd (II) Pd-Porph_2 To a solution of Porph_2 $(1.35 \mathrm{~g}, 1 \mathrm{mmol}, \mathrm{M}=1352.04 \mathrm{~g} / \mathrm{mol})$ in chloroform $(100 \mathrm{~mL})$ was added a solution of palladium acetate $(0.22 \mathrm{~g}, 1 \mathrm{mmol}, \mathrm{M}=224.51 \mathrm{~g} / \mathrm{mol})$ in methanol $(20 \mathrm{~mL})$. The mixture was refluxed for $1 \mathrm{~h}$. After cooled to room temperature, the solvent was removed under reduced pressure. After washing by methanol, the crude was purified by column chromatography $\left(\mathrm{SiO}_{2}\right)$ using chloroform) as the eluent to yield [5,10,15,20-tetrakis(4dodecyloxyphenyl) porphyrinate]Pd(II) $(1.23 \mathrm{~g}, 85 \%$ yield $)$ as a solid. ${ }^{1} \mathrm{H}-\mathrm{NMR}\left(\mathrm{CDCl}_{3}\right) \delta: 9.05$ $(8 \mathrm{H}, \mathrm{s}), 8.22(8 \mathrm{H}, \mathrm{d}, \mathrm{J}=9 \mathrm{~Hz}), 7.32(8 \mathrm{H}, \mathrm{d}, \mathrm{J}=9 \mathrm{~Hz}), 4.22(8 \mathrm{H}, \mathrm{t}, \mathrm{J}=7 \mathrm{~Hz}), 1.96(8 \mathrm{H}$, quint, $\mathrm{J}$ $=7 \mathrm{~Hz}), 1.61(8 \mathrm{H}$, quint, $\mathrm{J}=7 \mathrm{~Hz}), 1.25-1.55(\mathrm{~m}, 64 \mathrm{H}), 0.91(12 \mathrm{H}, \mathrm{t}, \mathrm{J}=7.0 \mathrm{~Hz})$; HRMS (ESI MS) m/z: theor: 1454.8657 found: $1454.8659\left(\mathrm{M}^{+\cdot}\right.$ detected).

Synthesis of [5,10,15,20-Tetrakis(2,4-dibutoxyphenyl)porphyrinate]Zn (II) Zn-Porph_4 To a solution of Porph_4 $(1.19 \mathrm{~g}, 1 \mathrm{mmol}, \mathrm{M}=1191.61 \mathrm{~g} / \mathrm{mol})$ in chloroform $(100 \mathrm{~mL})$ was added a solution of zinc acetate dihydrate $(0.25 \mathrm{~g}, 1 \mathrm{mmol}, \mathrm{M}=251.19 \mathrm{~g} / \mathrm{mol})$ in methanol (20 $\mathrm{mL}$ ). The mixture was refluxed for $1 \mathrm{~h}$. After cooled to room temperature, the solvent was removed under reduced pressure. After washing by methanol, the crude was purified by column 
chromatography $\left(\mathrm{SiO}_{2}\right)$ using chloroform) as the eluent to yield [5,10,15,20-tetrakis(4dodecyloxyphenyl) porphyrinate]zinc(II) $(0.60 \mathrm{~g}, 48 \%$ yield $)$ as a solid. ${ }^{1} \mathrm{H}-\mathrm{NMR}\left(\mathrm{CDCl}_{3}\right) \delta$ : $9.38(4 \mathrm{H}, \mathrm{d}, \mathrm{J}=9.0 \mathrm{~Hz}), 8.98(8 \mathrm{H}, \mathrm{s}), 6.61(4 \mathrm{H}, \mathrm{dd}, \mathrm{J}=9.0 \mathrm{~Hz}, \mathrm{~J}=2.2 \mathrm{~Hz}), 6.61(4 \mathrm{H}, \mathrm{d}, \mathrm{J}=2.2$ Hz), $4.08(8 \mathrm{H}, \mathrm{t}, \mathrm{J}=6.4 \mathrm{~Hz}), 4.07(8 \mathrm{H}, \mathrm{t}, \mathrm{J}=6.4 \mathrm{~Hz}), 1.76-1.94(16 \mathrm{H}, \mathrm{m}), 1.46-1.64(16 \mathrm{H}, \mathrm{m})$, $1 . .02(12 \mathrm{H}, \mathrm{t}, \mathrm{J}=7.3 \mathrm{~Hz}), 1.00(12 \mathrm{H}, \mathrm{t}, \mathrm{J}=7.3 \mathrm{~Hz})$; HRMS (ESI MS) m/z: theor: 1252.6207 found: $1252.6205\left(\mathrm{M}^{+} \cdot\right.$ detected $)$.

\section{Results and Discussion}

\subsection{Synthesis of porphyrins and metalloporphyrins}

Eight porphyrins Porph_1-Porph_8 were investigated in this work and the different dyes were synthesized following the Rothemund synthesis reported for the time in $1935^{[58,59]}$. More precisely, the simplified version of the Rothemund synthesis i.e. the Adler-Longo procedure was used. ${ }^{[60]}$ This procedure consists in a condensation/oxidation reaction of pyrrole and the appropriate aldehyde in propanoic acid used as the solvent (See Scheme 1). In our case, eight aromatic aldehydes Ald_1-Ald_7 were used and Porph_1-Porph_8 could be obtained with reaction yields ranging from 9 to $90 \%$.

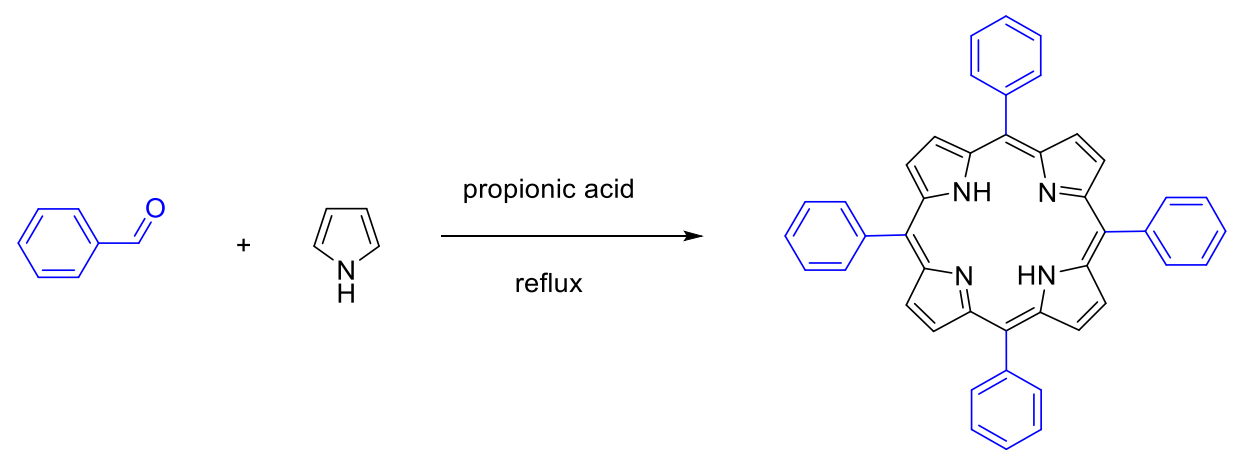

Scheme 1. The Adler-Longo synthesis of porphyrins.

Noticeably, the reaction yields obtained for Porph_1 ${ }^{[59-63]}$, Porph_2 ${ }^{[64]}$, Porph_3 ${ }^{[65]}$, Porph_6 ${ }^{[66-68]}$, Porph_7 ${ }^{[69]}$ and Porph_8 ${ }^{[70]}$ are consistent with those previously reported in the literature (See Scheme 2). Only Porph_4 and Porph_5 were not previously reported in the literature and these two porphyrins were prepared in 26 and $21 \%$ yields respectively. However, immediately after synthesis, Porph_3 and Porph_5-Porph_8 were discarded from the 
metalation step due to their insufficient solubilities. By using the appropriate solvent, Porph_1, Porph_2 and Porph_4 could undergo a rapid metal incorporation $\left(\mathrm{Cu}^{\mathrm{II}}, \mathrm{Zn}^{\mathrm{II}}, \mathrm{Fe}^{\mathrm{II}}\right.$ and $\left.\mathrm{Pd}^{\mathrm{II}}\right)$ so that six metalated porphyrins could be obtained with reaction yields ranging from $48 \%$ for $\mathbf{Z n -}$ Porph_4 to 95\% yield for Cu-Porph_2 (See Scheme 3).

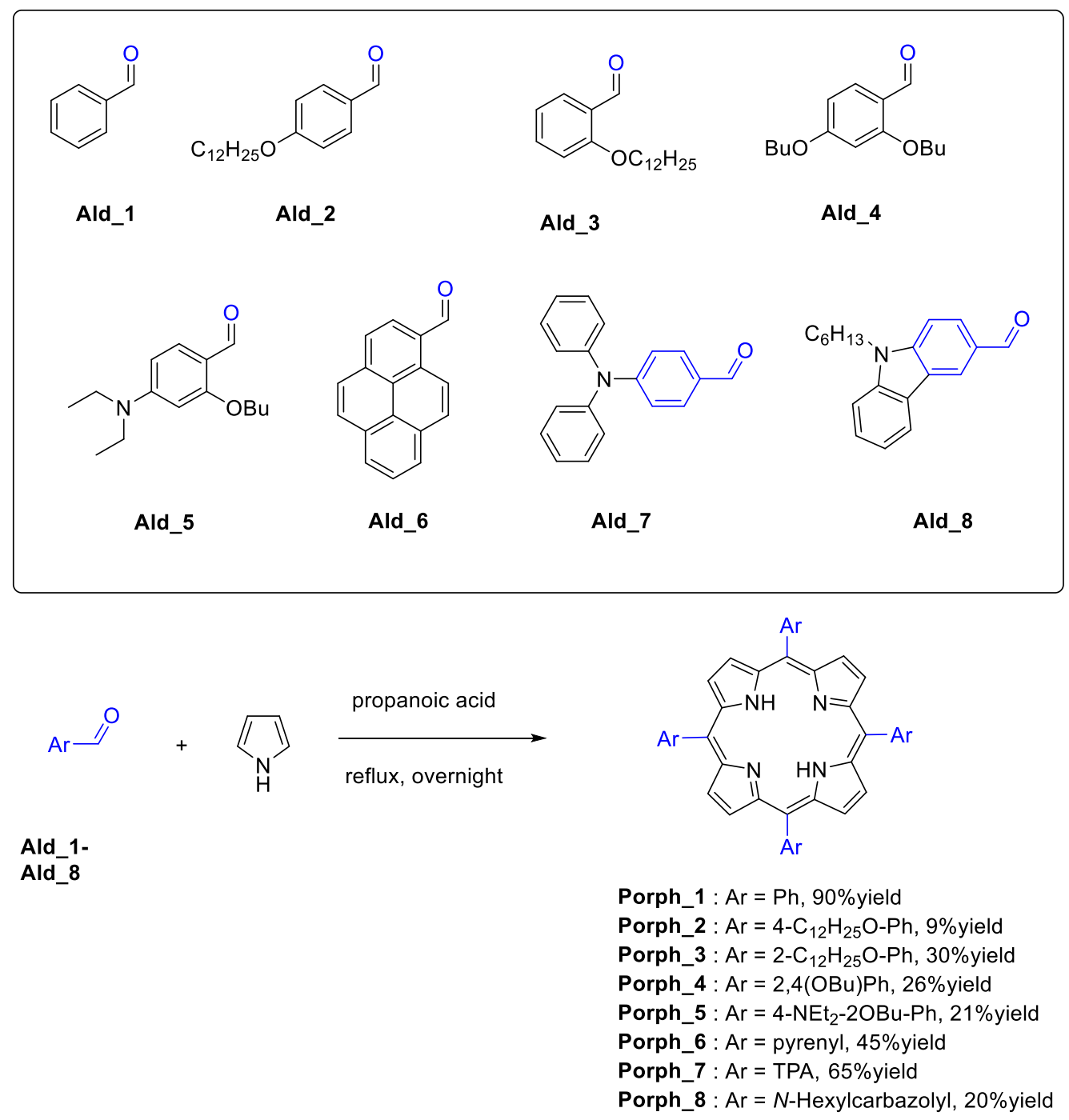

Scheme 2. Synthetic routes to porphyrins Porph_1-Porph_8. 


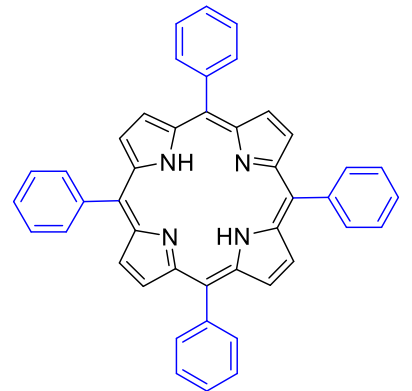

Porph_1

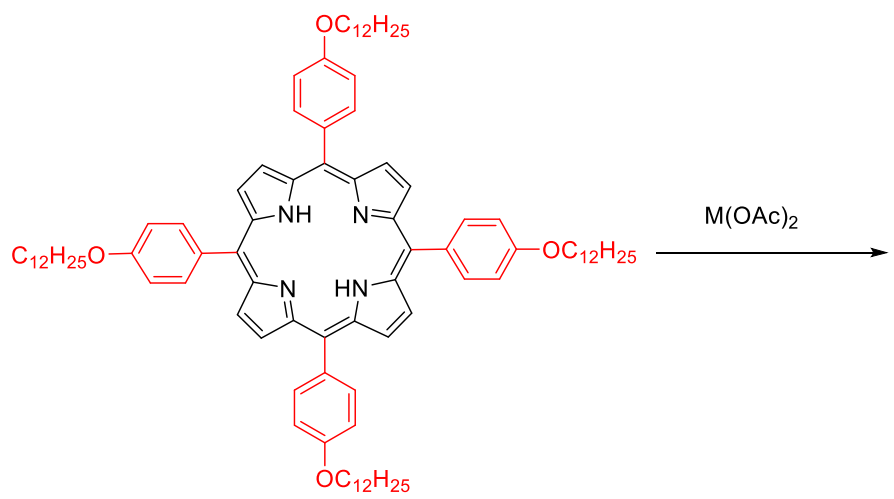

Porph_2

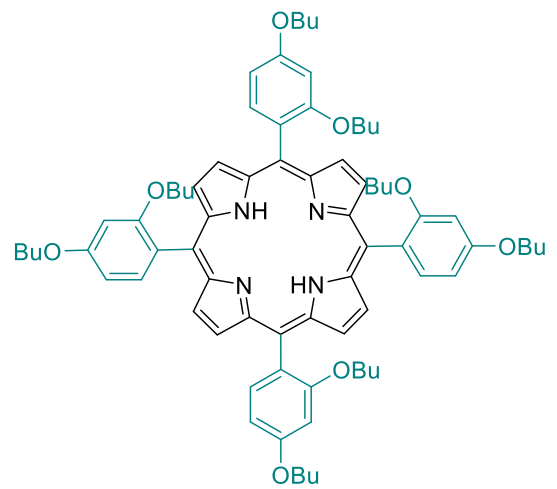

Porph_4

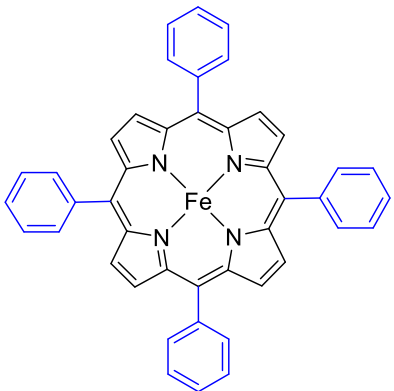

Fe-Porph_1

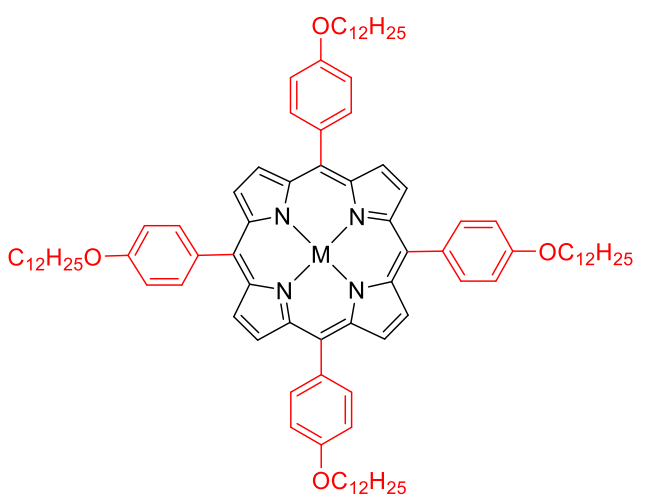

Cu-Porph_2: $\mathrm{M}=\mathrm{Cu}^{2+}, 95 \%$ yield Zn-Porph_2 : $\mathrm{M}=\mathrm{Zn}^{2+}, 54 \%$ yield Pd-Porph_2: $\mathrm{M}=\mathrm{Pd}^{2+}, 85 \%$ yield Fe-Porph_2 : $\mathrm{M}=\mathrm{Fe}^{2+}, 65 \%$ yield

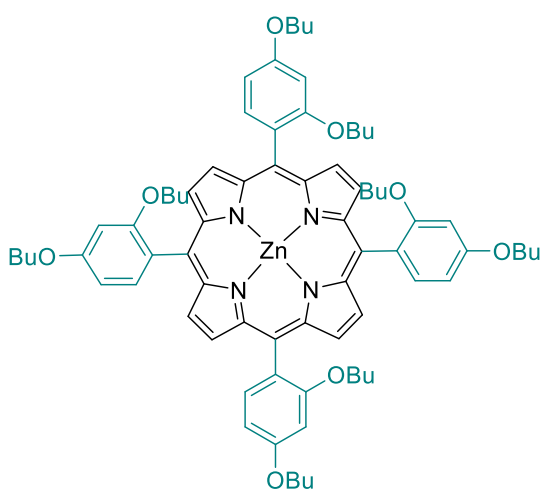

Zn-Porph_4

Scheme 3. Synthetic routes to metalloporphyrins Fe-Porph_1, Cu-Porph_2, Zn-Porph_2, Pd-Porph_2, Fe-Porph_2 and Zn-Porph_4.

\subsection{Light absorption properties of metallated porphyrins}

UV-visible absorption spectra of Fe-Porph_1, Cu-Porph_2, Zn-Porph_2, Pd-

Porph_2, Fe-Porph_2 and Zn-Porph_4 were recorded in chloroform. As shown in the Figure 3, all porphyrins showed an intense absorption band around $420 \mathrm{~nm}$ corresponding to the Soret 
band. While modifying the metal cation, the Soret band of the metalated porphyrins FePorph_1 and Fe-Porph_2 was not shifted but broadened compared to that observed for the other metal cations. Jointly, a severe reduction of the molar extinction coefficient was detected for the Fe-based porphyrins, peaking at $150000 \mathrm{~L} \cdot \mathrm{mol}^{-1} \cdot \mathrm{cm}^{-1}$. The highest molar extinction coefficients were determined for Cu-Porph_2 and Zn-Porph_2 peaking at 436000 and 465 $000 \mathrm{~L} \cdot \mathrm{mol}^{-1} \cdot \mathrm{cm}^{-1}$. Interestingly, introduction of additional electron-donating groups in $\mathbf{Z n -}$ Porph_4 contributed to drastically reduce the molar extinction coefficient of $\mathbf{Z n - P o r p h \_ 4}$ compared to that of Zn-Porph_2. Even if the absorption spectra of all porphyrins is centered in the 400-500 $\mathrm{nm}$ region, a non-negligible absorption can be detected in the 700-800 $\mathrm{nm}$ region with a molar extinction coefficient higher than $1000 \mathrm{~L} \cdot \mathrm{mol}^{-1} \cdot \mathrm{cm}^{-1}$. Absorption in this region typically corresponds to the Q-bands of the metalated porphyrins, originating from highfrequency molecular vibrations. Positions and intensities of these Q bands are notably highly dependent from the substitution pattern of the porphyrin core.[71-73] Therefore, contrarily to what is observed in the 350-450 nm region, Zn-Porph_2 showed the weakest absorption in the near-infrared region, with a maximum absorption lower than that of Zn-Porph_4. It has to be noticed that the $\mathrm{Q}$ bands correspond to vibronic couplings between the metal cation and the peripheral organic part so that the transitions detected in the near-infrared region would not be observed for none-metalated porphyrins. Despites their low absorption in the near-infrared region, the absorption of the different metalated dyes was sufficient to be used for photoinitiation processes.

\subsection{Photoinitiation ability of the porphyrin-based systems.}

\subsubsection{Photoinitiating ability @405nm}

Photoinitiating ability of the different metalated porphyrins was examined first for the Free Radical Polymerization (FRP) of a methacrylate resin (MIX-MA) upon excitation at 405 $\mathrm{nm}$ in presence of iodonium salt and phosphine as additives. Absorptions of porphyrins are mainly centered in the 400-600 nm region (See Figure 3) with high molar extinction coefficients, 
therefore three of them were found as efficient initiators for the polymerization of methacrylates under air (See Table 1).
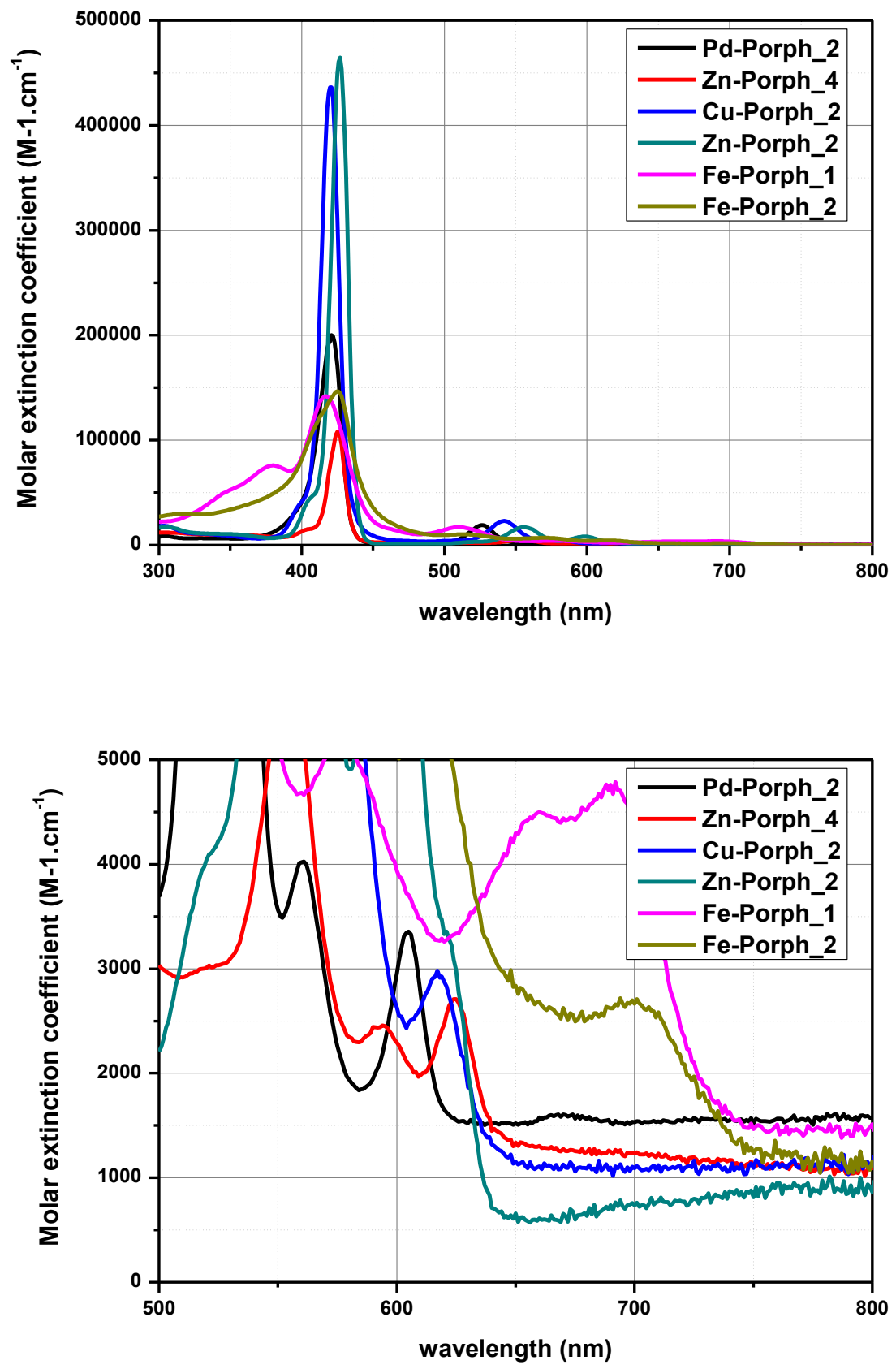

Figure 3. UV-visible absorption spectra of Fe-Porph_1, Cu-Porph_2, Zn-Porph_2, PdPorph_2, Fe-Porph_2 and Zn-Porph_4 in chloroform (top) expansion of the UV-visible absorption spectra of the same porphyrins in the 500-800 $\mathrm{nm}$ region. 
For the other porphyrin-based systems, the final methacrylate function conversion remained quite low $(<30 \%)$; these latter systems were not able to overcome the oxygen inhibition. As shown in our previous work for ZnTPP, the porphyrin can sensitize the iodonium salt decomposition through $\mathrm{r} 1$ to generate highly efficient initiating aryl radicals (See mechanism depicted in the mechanistic part). Presence of the phosphine helps to overcome the oxygen inhibition in r4-r5 but can also regenerate the porphyrins in r6 (see below). ${ }^{[31]}$

Table 1. Final methacrylate function conversions (FC) under air for the MIX-MA after 400s of irradiation using a LED@405nm

\begin{tabular}{|c|c|}
\hline $\begin{array}{c}\text { Initiating systems } \\
(0.1 \% / 1 \% / 1 \%)\end{array}$ & $\begin{array}{c}\text { methacrylate function conversion (FC) } \% \\
(\text { at } \mathrm{t}=400 \mathrm{~s})\end{array}$ \\
\hline Fe-Porph_1/Iod/4-dppba & $50 \%$ \\
\hline Zn-Porph_2/Iod/4-dppba & $75 \%$ \\
\hline Zn-Porph_4/Iod/4-dppba & $74 \%$ \\
\hline
\end{tabular}

\subsubsection{Photoinitiating ability Upon NIR light}

Photoinitiating ability of the different metalated porphyrins was extended for the FRP of MIX-MA upon excitation at $785 \mathrm{~nm}$. As mentioned in the introduction section, the polymerization of acrylate or methacrylate is exothermic so that the FRP of MIX-MA was examined for a four-component system comprising the two additives, namely the iodonium salt (Iod) and the phosphine (4-dppba) which is commonly used to reduce oxygen inhibition, ${ }^{\text {[61-62] }}$ and the thermal initiator BlocBuilder MA.

To carry out the photopolymerization experiments, the optical density at $785 \mathrm{~nm}$ was selected to be lower than 0.1 to ensure a good light penetration inside the photocurable resin. The absorption in monomer is slightly different than in chloroform, but the NIR absorption of the investigated compounds remain low. Indeed, for high optical density, an inner filter effect 
occurs, adversely affecting the polymerization in depth by limiting the light penetration. Especially, all porphyrins examined in this work exhibit low molar extinction coefficients at $785 \mathrm{~nm}$ which corresponds to the irradiation wavelength, avoiding the inner filter effect. Conversely, for dyes absorbing in the near-infrared region, light-triggered heat release is wellreported and notably used for phototherapy or drug delivery. ${ }^{[63-65]}$ In the context of photopolymerization, NIR dyes can absorb light and convert it into heat i.e. these dyes have a heater behavior. As a result of this, heat can be dissipated through the whole resin via convective heat transfer and if the temperature reached by the resin is sufficient, a thermal initiator of polymerization can be decomposed, producing initiating species. This is the reason why, in this work, polymerization processes were carried out upon NIR excitation, to decompose the iodonium salt by a pure photochemical process ( $\mathrm{r} 1)$ and concomitantly to decompose a thermal initiator by light-triggered heat release (r2-r3) corresponding to a photothermal process. The exothermicity of the polymerization reaction also participates to the heat release to promote the decomposition of the thermal photoinitiator. As the thermal initiator, Blockbuilder ${ }^{\circledR}$ MA which is a thermosensitive alkoxyamine was selected for its low decomposition temperature ranging between 50 and $70^{\circ} \mathrm{C} .{ }^{[66-68]}$ Choice of Blockbuilder® MA (See chemical structure in Figure 2) as the thermal initiator was motivated by the following reasons 1) BlocBuilder® MA is extensively used for the polymerization of methacrylates. 2) homolysis of the C-ON bond is well-documented in the literature 3) BlocBuilder ${ }^{\circledR}$ MA opens the way towards living radical polymerization. Indeed, thermosensitive alkoxyamines are at the basis of a polymerization technique named the nitroxide mediated polymerization (NMP) $\left.{ }^{[67]} 4\right)$ this thermal initiator exhibits a low dissociation temperature and 5) this thermal initiator is commercially available and used as a benchmark initiator in industry.

Noticeably, a NIR polymerization process could only be detected for three metalated porphyrins, namely, Fe-Porph_1, Zn-Porph_2 and Zn-Porph_4. For the four other metalated porphyrins, no polymerization could be detected, even after $1000 \mathrm{~s}$ of irradiation at $785 \mathrm{~nm}$. A 
relatively long inhibition time could be determined with all photoinitiating systems, around 200 $\mathrm{s}$, resulting from a strong oxygen inhibition despite the presence of 4-dppba in the resin (See Figure 4). The thicknesses of the samples have been controlled to check that conversion can't be ascribed to such a change of thickness. After $1000 \mathrm{~s}$ of irradiation, the four-component system based on Fe-Porph_1 as the photosensitizer could reached a final methacrylate function conversion of 55\%, close to that obtained with Zn-Porph_4 (50\% methacrylate function conversion). The final methacrylate function conversion without BlocBuilder MA (e.g. for ZnPorph_2/Iod/4-dppba system) is only 30\% (vs. 50\% in presence of BlocBuilder), clearly showing the interest of the photothermal effect combined with the presence of thermal initiator to improve the polymerization initiating ability (see the chemical mechanisms below). Considering that the three metalated porphyrins strongly differs by the metal cation and the substitution pattern of the porphyrin core, no structure performance can be established. Besides, it can be noticed that two of the three porphyrins that were capable to initiate a polymerization process comprise a $\mathrm{Zn}^{2+}$ cation, giving a first trend for future works. These results are consistent with our previous works on ZnTPP @ $405 \mathrm{~nm}^{[31]}$ and the extensive use of Zn-porphyrins as photocatalysts for the degradation of various pollutants, ${ }^{[69,70,74,75]}$ hydrogen production ${ }^{[76]}$ or $\mathrm{CO}_{2}$ reduction. ${ }^{[77-78]}$ To support the polymerization process observed upon irradiation with a LED at $785 \mathrm{~nm}$, the following equations $\mathrm{r} 1-\mathrm{r} 5$ can be proposed. Indeed, initiating radicals formed upon photoexcitation can be generated according to two parallel mechanisms: 1) a pure photochemical pathway which is classically observed during photopolymerization consisting in the interaction of the excited dye with the iodonium salt. As a result of this, a photoreduction process occur, reducing the iodonium salt and leading to the formation of aryl radicals which are very efficient initiating species (see equation r1). 2) Parallel the photochemical process, a photothermal effect can also take place, the dye being capable to convert the NIR light into heat. When the temperature of the photocurable resin is sufficient, the thermal initiator can decompose, providing a second source of initiating radicals (See equations r2-r3). Considering 
that FRP is adversely affected by oxygen and that all polymerization experiments have been carried out under air, phosphines are classically used to overcome the oxygen inhibition by mean of the equations r4-r5. ${ }^{[79]}$ The temperature was controlled as presented by us in $[15,16,17]$ by thermal imaging experiments. It is shown that temperature higher than $60^{\circ} \mathrm{C}$ can be reached after 100s of NIR irradiation allowing the decomposition of BlocBuilder.

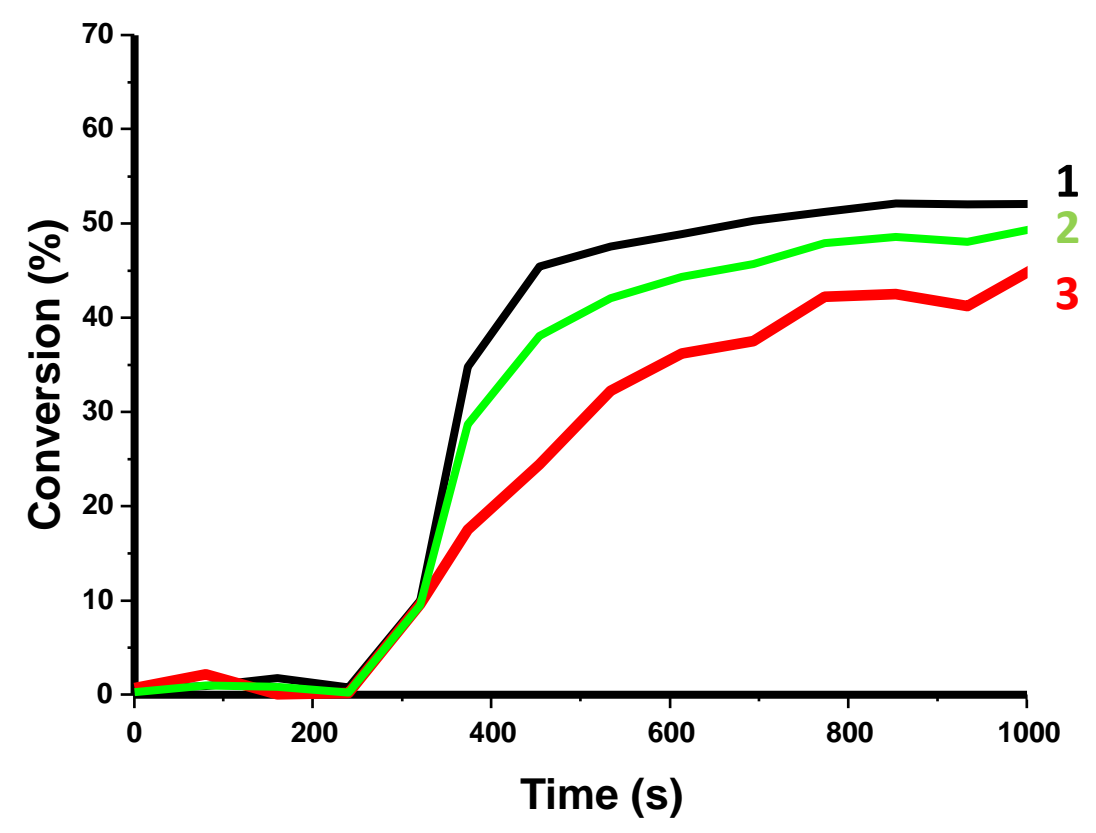

Figure 4. Photopolymerization profiles for Mix-MA in air (methacrylate function conversion vs. irradiation time) in the presence of $\mathrm{Ar}_{2} \mathrm{I}^{+} / \mathrm{PF}_{6}{ }^{-}$(3 wt $\%$ ), 4-dppba (2 wt \%), BlocBuilder MA (2 wt \%), and (1) Fe-Porph_1 (0.1 wt\%), (2) Zn-Porph_2 (0.1 wt\%) and (3) Zn-Porph_4 (0.1 wt $\%)$, using a laser diode @ $785 \mathrm{~nm}\left(\mathrm{I}=2.5 \mathrm{~W} . \mathrm{cm}^{-2}\right)$; thickness = $1.4 \mathrm{~mm}$; the irradiation starts at $\mathrm{t}=17 \mathrm{~s}$.

As interesting feature, phosphines are capable to convert the non-initiating peroxy radicals $\left(\mathrm{ROO}^{\bullet}\right)$ into the reactive alkoxy radicals $\left(\mathrm{RO}^{\bullet}\right)$ (See Scheme 4). Indeed, as reported by Buckler as soon as 1962, autooxydation of arylphosphine by peroxy radicals can occur via a radical attack of peroxy radicals on the heteroatom of phosphines, inducing a valence expansion 
for the phosphor atom and furnishing a short-lived phosphoranyl radical. Finally, by mean of a $\beta$-scission, initiating species $\mathrm{RO}^{\bullet}$ can be obtained. ${ }^{[80-81]}$ Parallel to this, the phosphine can also contribute to reduce the oxidized photosensitizer, regenerating it and maintaining the concentration of photosensitizer constant within the resin (See equation r6). Overall, by combining a photochemical and a thermal polymerization pathway and by using a phosphine in charge to convert the non-initiating peroxy radicals into reactive radicals, radicals of various types can be simultaneously formed, optimizing the production of radicals and resulting in remarkable polymerization profiles.

$$
\begin{aligned}
& \text { dye } \rightarrow \text { *dye }(\mathrm{h} v) \\
& * \text { dye }+\mathrm{Ar}_{2} \mathrm{I}^{+} \rightarrow \text { dye }{ }^{\bullet+}+\mathrm{Ar}^{\bullet}+\mathrm{ArI} \\
& * \text { dye } \rightarrow \text { dye }+\Delta \\
& \text { Blocbuilder }+\Delta \rightarrow \text { free radicals } \\
& \mathrm{ROO}^{\bullet}+\mathrm{PAr}_{3} \rightarrow \mathrm{ROO}-\mathrm{P}^{\bullet} \mathrm{Ar}_{3} \\
& \mathrm{ROO}^{-\mathrm{P}^{\bullet} \mathrm{Ar}_{3} \rightarrow \mathrm{RO}}+\mathrm{O}=\mathrm{PAr}_{3} \\
& \text { dye } \\
& \bullet+\mathrm{PAr}_{3} \rightarrow \text { dye }+\mathrm{PAr}_{3}^{\bullet+}
\end{aligned}
$$

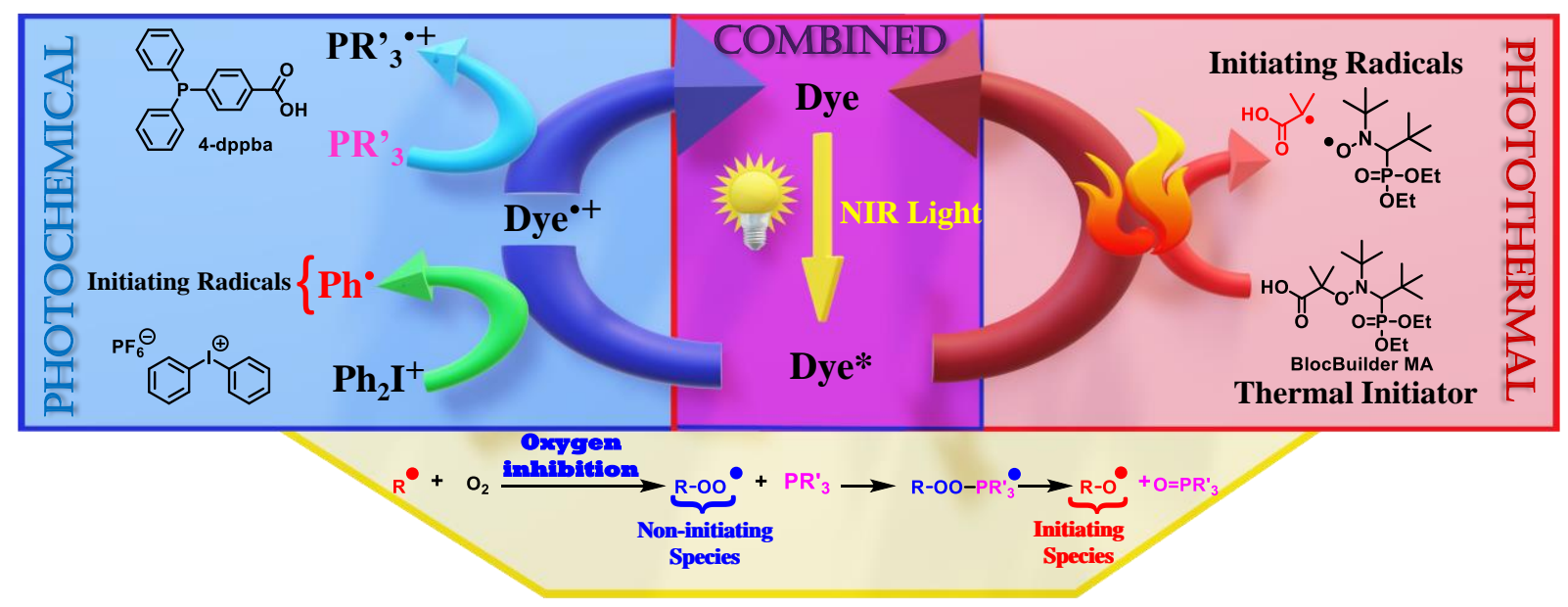

Scheme 4. Overview of the chemical mechanism.

\section{Conclusion}


To conclude, a series of eight porphyrins have been designed and synthesized for their subsequent metalation with various metal cations. Due to the insolubility of Porph_3 and Porph_5-Porph_8, these porphyrins have been discarded for the design of photoinitiators. Six porphyrins could be successfully metalated with iron, zinc and palladium cations. When tested as photoinitiator/photosensitizer for four-component systems in the NIR, only three of them proved to be efficient and final methacrylate function conversion between 40 and $55 \%$ could be obtained with the different systems. Especially, their ability to initiate a polymerization at $785 \mathrm{~nm}$ has been clearly evidenced. Interestingly, Zn-porphyrins seems to be better candidates for photoinitiation, what is consistent with their well-established photocatalytic activity reported for the photodegradation of pollutant, hydrogen production or $\mathrm{CO}_{2}$ reduction. Considering the paucity of structures examined in this work, future work will consist in developing a wide of structure to establish a structure-performance relationship in NIR systems.

\section{Acknowledgements}

The Agence Nationale de la Recherche (ANR agency) is acknowledged for funding through the PhD grant of Guillaume Noirbent (ANR-17-CE08-0054 VISICAT project). Aix Marseille University and the Centre National de la Recherche Scientifique (CNRS) are acknowledged for permanent fundings.

\section{References}

[1] A. Bagheri, J Jin, Photopolymerization in 3D Printing, ACS Appl. Polym. Mater. 1 (2019) 593-611.

[2] J.V. Crivello, E. Reichmanis, Photopolymer materials and processes for advanced technologies, Chem. Mater. 26 (2014) 533-548.

[3] K. Hamada, M. Kaseem, F. Deri, Recycling of waste from polymer materials: An overview of the recent works, Polym. Degrad. Stab. 98 (2013) 2801-2812. 
[4] J. Hopewell, R. Dvorak, E. Kosior, Plastics recycling: challenges and opportunities, Phil. Trans. R. Soc. B 364 (2009) 2115-2126.

[5] P. Xiao, J. Zhang, F. Dumur, M.-A. Tehfe, F. Morlet-Savary, B. Graff, D. Gigmes, J.P. Fouassier, J. Lalevée, Photoinitiating systems: recent progress in visible light induced cationic and radical photopolymerization reactions under soft conditions, Prog. Polym. Sci. 41 (2015) 32-66.

[6] P. Xiao, M. Frigoli, F. Dumur, B. Graff, D. Gigmes, J.-P. Fouassier, J. Lalevée, Julolidine or fluorenone based push-pull dyes for polymerization upon soft polychromatic visible light or green light, Macromolecules 47 (2014) 106-112.

[7] M.-A. Tehfe, F. Dumur, B. Graff, F. Morlet-Savary, D. Gigmes, J.-P. Fouassier, J. Lalevée, Push-pull (thio)barbituric acid derivatives in dye photosensitized radical and cationic polymerization reactions under 457/473 nm Laser beams or blue LEDs, Polym. Chem. 4 (2013) 3866-3875.

[8] P. Xiao, F. Dumur, B. Graff, L. Vidal, D. Gigmes, J.-P. Fouassier, J. Lalevée, Structural effects in the indanedione skeleton for the design of low intensity 300-500 nm light sensitive initiators, Macromolecules 47 (2014) 26-34.

[9] P. Xiao, F. Dumur, B. Graff, J.-P. Fouassier, D. Gigmes, J. Lalevée, Cationic and thiolene photo-polymerization upon red lights using anthraquinone derivatives as photoinitiators, Macromolecules 46 (2013) 6744-6750.

[10] M.-A. Tehfe, D. Gigmes, F. Dumur, F. Morlet-Savary, B. Graff, J. Lalevée, J.-P. Fouassier, Cationic photosensitive formulations based on silyl radical chemistry for green and red diode laser exposures, Polym. Chem. 3 (2012) 1899-1902.

[11] P. Garra, C. Dietlin, F. Morlet-Savary, F. Dumur, D. Gigmes, J.-P. Fouassier, J. Lalevée, Photopolymerization of thick films and in shadow areas: A review for the access to composites, Polym. Chem. 8 (2017) 7088-7101. 
[12] A.-H. Bonardi, F. Morlet-Savary, T.M. Grant, F. Dumur, G. Noirbent, D. Gigmes, B.H. Lessard, J.-P. Fouassier, J. Lalevée, High performance near infrared (NIR) photoinitiating systems operating under low light intensity and in presence of oxygen, Macromolecules 51 (2018) 1314-1324.

[13] P. Garra, F. Dumur, M. Nechab, F. Morlet-Savary, C. Dietlin, B. Graff, D. Gigmes, J.P. Fouassier, J. Lalevée, Stable copper acetylacetonate-based oxidizing agents in redox (NIR photoactivated) polymerization: an opportunity for one pot grafting from approach and example on a 3D printed object, Polym. Chem. 9 (2018) 2173-2182.

[14] A.H. Bonardi, F. Bonardi, G. Noirbent, F. Dumur, C. Dietlin, D. Gigmes, J.-P. Fouassier, J. Lalevée, Different NIR dye scaffolds for polymerization reactions under NIR light, Polym. Chem. 10 (2019) 6505-6514.

[15] A.-H. Bonardi, F. Bonardi, G. Noirbent, F. Dumur, D. Gigmes, C. Dietlin, J. Lalevée, Free radical polymerization upon near-infrared light irradiation, merging photochemical and photothermal initiating methods, J. Polym. Sci. A Polym. Chem. 58 (2020) 300-308.

[16] A.-H. Bonardi, F. Bonardi, F. Dumur, D. Gigmes, J. Lalevée, Fillers as heaters for photothermal polymerization upon NIR light, Macromol. Rapid. Commun. 40 (2019) 1900495.

[17] A.-H. Bonardi, F. Bonardi, F. Morlet-Savary, C. Dietlin, G. Noirbent, T.M. Grant, J.-P. Fouassier, F. Dumur, B.H. Lessard, D. Gigmes, J. Lalevée, Photoinduced thermal polymerization reactions. Macromolecules 51 (2018) 8808-8820.

[18] G. Noirbent, Y. Xu, A.-H. Bonardi, S. Duval, D. Gigmes, J. Lalevée, F. Dumur, New donor-acceptor Stenhouse adducts as visible and near infrared light photoinitiators of polymerization, Molecules 25 (2020) 2317.

[19] H. Mokbel, B. Graff, F. Dumur, J. Lalevée, NIR sensitizer operating under long wavelength $(1064 \mathrm{~nm})$ for free radical photopolymerization processes, Macromol. Rapid Commun. 41 (2020) 2000289. 
[20] A. Caron, F. Dumur, J. Lalevée, Near-Infrared induced photothermal decomposition of Charge Transfer Complexes: a new way to initiate thermal polymerization, J. Polym. Sci. 58 (2020) 2134-2139.

[21] H. Mokbel, F. Dumur, J. Lalevée, On demand NIR activated photopolyaddition reactions, Polym. Chem. 11 (2020) 4250-4259.

[22] P. Brogdon, H. Cheema, J.-H. Delcamp, Near-infrared-absorbing metal-free organic, porphyrin, and phthalocyanine sensitizers for panchromatic dye-sensitized solar cells, ChemSusChem 11 (2018) 86-103.

[23] A. Abuteen, S. Zanganeh, J. Akhigbe, L.P. Samankumara, A. Aguirre, N. Biswal, M. Braune, A. Vollertsen, B. Roder, C. Bruckner, Q. Zhu, Q. The evaluation of NIRabsorbing porphyrin derivatives as contrast agents in photoacoustic imaging, Phys. Chem. Chem. Phys. 15 (2013) 18502-18509.

[24] S. Shanmugam, J. Xu, C. Boyer, exploiting metalloporphyrins for selective living radical polymerization tunable over visible wavelengths, J. Am. Chem. Soc. 137 (2015) 9174-9185.

[25] Y. Zhao, M. Yu, X. Fu, Photo-cleavage of the cobalt-carbon bond: visible light-induced living radical polymerization mediated by organo-cobalt porphyrins, Chem. Commun. 49 (2013) 5186-5188.

[26] C.-S. Hsu, T.-Y. Yang, C.-H. Peng, Vinyl acetate living radical polymerization mediated by cobalt porphyrins: kinetic- mechanistic studies, Polym. Chem. 5 (2014) $3867-3875$.

[27] Y. Zhao, M. Yu, S. Zhang, Y. Liu, X. Fu, Visible light induced living/controlled radical polymerization of acrylates catalyzed by cobalt porphyrins, Macromolecules 47 (2014) 6238-6245.

[28] C.-H. Peng, S. Li, B.B. Wayland, Aspects of living radical polymerization mediated by cobalt porphyrin complexes, J. Chin. Chem. Soc. 56 (2009) 219-233. 
[29] S. Shanmugam, J. Xu, C. Boyer, Utilizing the electron transfer mechanism of chlorophyll a under light for controlled radical polymerization, Chem. Sci. 6 (2015) $1341-1349$.

[30] M. da G.H. Vicente, K.M. Smith, Syntheses and functionalizations of porphyrin macrocycles, Curr. Org. Synth. 11 (2014) 3-28.

[31] A. Al Mousawi, C. Poriel, F. Dumur, J. Toufaily, T. Hamieh, J.-P. Fouassier, J. Lalevée, Zinc tetraphenylporphyrin as high performance visible light photoinitiator of cationic photosensitive resins for led projector 3d printing applications, Macromolecules 50 (2017) 746-753.

[32] P. Xiao, F. Dumur, J. Zhang, B. Graff, D. Gigmes, J.-P. Fouassier, J. Lalevée, New role of aminothiazo-naphthalimide derivatives: outstanding photoinitiators for cationic and radical photopolymerizations under visible LEDs, RSC Adv. 6 (2016) 48684-48693.

[33] P. Xiao, F. Dumur, B. Graff, F. Morlet-Savary, D. Gigmes, J.-P. Fouassier, J. Lalevée, Design of high performance photoinitiators at 385-405 nm: search around the naphthalene scaffold, Macromolecules 47 (2014) 973-978.

[34] K. Matyjaszewski, B.E. Woodworth, X. Zhang, S.G. Gaynor, Z. Metzner, Simple and efficient synthesis of various alkoxyamines for stable free radical polymerization, Macromolecules 31 (1998) 5955-5957.

[35] D. Bertin, D. Gigmes, S.R.A. Marque, P. Tordo, Kinetic subtleties of nitroxide mediated polymerization, Chem. Soc. Rev. 40 (2011) 2189-2198.

[36] F. Chauvin, P.E. Dufils, D. Gigmes, Y. Guillaneuf, S.R.A. Marque, P. Tordo, D. Bertin, Nitroxide-mediated polymerization: The pivotal role of the kd value of the initiating alkoxyamine and the importance of the experimental conditions, Macromolecules 39 (2006) 5238-5250. 
[37] P. Xiao, W. Hong, Y. Li, F. Dumur, B. Graff, J.-P. Fouassier, D. Gigmes, J. Lalevée, Green light sensitive diketopyrrolopyrrole derivatives used in versatile photoinitiating systems for photopolymerizations, Polym. Chem. 5 (2014) 2293-2300.

[38] Y.Y. Xu, Z.F. Ding, F.Y. Liu, K. Sun, C. Dietlin, J. Lalevee, P. Xiao, 3D Printing of olydiacetylene photocomposite materials: two wavelengths for two orthogonal chemistries. ACS Appl. Mater. Interf. 12 (2020) 1658-1664.

[39] P. Xiao, F. Dumur, B. Graff, D. Gigmes, J.-P. Fouassier, J. Lalevée, Variations on the benzophenone skeleton: novel high-performance blue light sensitive photoinitiating systems, Macromolecules 46 (2013) 7661-7667.

[40] R. Forschner, J. Knelles, K. Bader, C. Meller, W. Frey, A. Kçhn, Y. Molard, F. Giesselmann, S. Laschat, Flavylium salts: a blooming core for bioinspired ionic liquid crystals, Chem. Eur. J. 25 (2019) 12966-12980.

[41] W. Delong, W. Lanying, W. Yongling, S. Shuang, F. Juntao, Z. Xing, Natural amethylene lactam analogues: Design, synthesis and evaluation of a-alkenyl-g and dlactams as potential antifungal agents against Colletotrichum orbiculare, Eur. J. Med. Chem. 130 (2017) 286-307.

[42] A.J. Pollard, E.W. Perkins, N.A. Smith, A. Saywell, G. Goretzki, A.G. Phillips, S.P. Argent, H. Sachdev, F. Müller, S. Hüfner, S. Gsell, M. Fischer, M. Schreck, J. Osterwalder, T. Greber, S. Berner, N.R. Champness, P.H. Beton, Supramolecular assemblies formed on an epitaxial graphene superstructure, Angew. Chem. Int. Ed. 49 (2010) 1794-1799.

[43] C. Pigot, G. Noirbent, T.-T. Bui, S. Peralta, D. Gigmes, M. Nechab, F. Dumur, Pushpull chromophores based on the naphthalene scaffold: Potential candidates for optoelectronic applications, Materials 12 (2019) 1342. 
[44] G. Dey, P. Gaur, R. Giri, S. Ghosh, Optical signaling in biofluids: a nondenaturing photostable molecular probe for serum albumins, Chem. Commun. 52 (2016) 18871890.

[45] H. Cao, G. Wang, Y. Xue, G. Yang, J. Tian, F. Liu, W. Zhang, Far-red light-induced reversible addition-fragmentation chain transfer polymerization using a man-made bacteriochlorin, ACS Macro Lett. 8 (2019) 616-622.

[46] S. Sakthinathan, S. Kubendhiran, S.-M. Chen, M. Govindasamy, F.M.A. Al-Hemaid, M. Ajmal Ali, P. Tamizhdurai, S. Sivasanker, Metallated porphyrin noncovalent interaction with reduced graphene oxide-modified electrode for amperometric detection of environmental pollutant hydrazine, Appl. Organometal. Chem. 31 (2017) e3703.

[47] S. Sakthinathan, S. Kubendhiran, S.-M. Chen, K. Manibalan, M. Govindasamy, P. Tamizhdurai, S.T. Huang, Reduced graphene oxide non-covalent functionalized with zinc tetra phenyl porphyrin nanocomposite for electrochemical detection of dopamine in human serum and rat brain samples, Electroanalysis 28 (2016) 2126-2135.

[48] J. Liu, X. Yang, L. Sun, Axial anchoring designed silicon-porphyrin sensitizers for efficient dye-sensitized solar cells, Chem. Commun. 49 (2013) 11785-11787.

[49] Fan, Y. Huang, Y. Jiang, X. Ning, X. Wang, D. Shan, X. Lu, Comparative study on the interfacial electron transfer of zinc porphyrins with meso-p-extension at a $2 \mathrm{n}$ pattern, $\mathrm{J}$. Colloid Interf. Sci. 462 (2016) 100-109.

[50] R. Bera, S. Chakraborty, S.K. Nayak, B. Jana, A. Patra, Structural insight and ultrafast dynamics of 2D porphyrin nanostructures, J. Phys. Chem. C 123 (2019) 15815-15826.

[51] G. Magnano, D. Marinotto, M.P. Cipolla, V. Trifiletti, A. Listorti, P.R. Mussini, G. Di Carlo, F. Tessore, M. Manca, A. Orbelli Biroli, M. Pizzottia, Influence of alkoxy chain envelopes on the interfacial photoinduced processes in tetraarylporphyrin-sensitized solar cells, Phys. Chem. Chem. Phys. 18 (2016) 9577-9585. 
[52] W. Wu, W. Wu, S. Ji, H. Guo, X. Wang, J. Zhao, The synthesis of 5,10,15,20tetraarylporphyrins and their platinum (II) complexes as luminescent oxygen sensing materials, Dyes Pigm. 89 (2011) 199-211.

[53] N. Sheng, P.-H. Zhu, C.-Q. Maa, J.-Z. Jiang, The synthesis, spectroscopy, electrochemistry and photophysical properties of novel, sandwich europium (III) complexes with a porphyrin ligand bearing four pyrenyl groups in meso-positions, Dyes Pigm. 81 (2009) 91-96.

[54] Zoltan, F. Vargas, C. Rivas, V. López, J. Perez, A. Biasutto, Synthesis, photochemical and photoinduced antibacterial activity studies of meso-tetra(pyren-1-yl)porphyrin and its Ni, Cu and Zn complexes, Sci. Pharm. 78 (2010) 767-790.

[55] E.H. Tawfik, A.A. Fadd, N.N. Soliman, L. Abou-Zeid, A. Negm, New approach for the synthesis, docking of new porphyrins and their antitumor activity, J. Porphyr. Phthalocya. 23 (2019) 251-259.

[56] C.J. Walsh, T. Sooksimuang, B.K. Mandal, Synthesis and characterization of zinc(II) meso-tetra(9-hexyl) carbazolylporphine. A green-emitting hole transporting material for electroluminescent and photoconductive applications, J. Porphyr. Phthalocya. 5 (2001) 803-805.

[57] Z. Dong, P.J. Scammells, New methodology for the N-demethylation of opiate alkaloids, J. Org. Chem. 72 (2007) 9881-9885.

[58] P. Rothemund, A new porphyrin synthesis: the synthesis of porphin, J. Am. Chem. Soc. 58 (1936) 625-627.

[59] P. Rothemund, Formation of porphyrins from pyrrole and aldehydes, J. Am. Chem. Soc. 57 (1935) 2010-2011.

[60] A.D. Adler, F.R. Longo, J.D. Finarelli, J. Goldmacher, J. Assour, L. Korsakoff, A Simplified Synthesis for meso-Tetraphenylporphin, J. Org. Chem. 32 (1967) 476. 
[61] C. Belon, X. Allonas, C. Croutxé-Barghorn, J. Lalevée, Overcoming the oxygen inhibition in the photopolymerization of acrylates: A study of the beneficial effect of triphenylphosphine, J. Polym. Sci. A: Polym. Chem. 48 (2010) 2462-2469.

[62] S. Clark Ligon, B. Husár, H. Wutzel, R. Holman, R. Liska, Strategies to Reduce Oxygen Inhibition in Photoinduced Polymerization, Chem. Rev. 114 (2014) 557-589.

[63] M.L. Viger, W. Sheng, K. Doré, A.H. Alhasan, C.J. Carling, J. Lux, C. de Gracia Lux, M. Grossman, R. Malinow, A. Almutairi, Near-infrared-induced heating of confined water in polymeric particles for efficient payload release, ACS Nano. 8 (2014) 48154826.

[64] J. Cao, J. Chi, J. Xia, Y. Zhang, S. Han, Y. Sun, Iodinated cyanine dyes for fast nearinfrared-guided deep tissue synergistic phototherapy, ACS Appl. Mater. Interf. 11 (2019) $25720-25729$.

[65] T.-M. Liu, J. Conde, T. Lipiński, A. Bednarkiewicz, C.-C. Huang, Revisiting the classification of NIR-absorbing/emitting nanomaterials for in vivo bioapplications, NPG Asia Mater. 8 (2016) e295.

[66] D. Gigmes, P.-E. Dufils, D. Glé, D. Bertin, C. Lefay, Y. Guillaneuf, Intermolecular radical 1,2-addition of the BlocBuilder MA alkoxyamine onto activated olefins: a versatile tool for the synthesis of complex macromolecular architecture, Polym. Chem. 2 (2011) 1624-1631.

[67] For more references see Nitroxide Mediated Polymerization: From Fundamentals to Applications in Materials Science, D. Gigmes, Ed.; RSC Polym. Chem. Ser. No. 19, 2016. ISBN 978-1782620617.

[68] D.F. Grishin, I.D. Grishin, I. D. Mechanisms of Polymer Polymerization. In Polymeric Materials for Clean Water; Das, R., Ed.; Springer Series on Polymer and Composite Materials; Springer International Publishing: Cham, 2019; pp 7-58 
[69] S. Rui Chen, Synthesis of novel zinc porphyrins and their photocatalytic activity, Pigm. Resin Technol. 47 (2018) 360-366.

[70] E. Regulska, D.M. Rivera-Nazario, J. Karpinska, M.E. Plonska-Brzezinska, L. Echegoyen, Zinc porphyrin-functionalized fullerenes for the sensitization of titania as a visible-light active photocatalyst: river waters and wastewaters remediation, Molecules $24(2019) 1118$.

[71] A. Stradomskaa, Jasper Knoester, Shape of the Q band in the absorption spectra of porphyrin nanotubes: Vibronic coupling or exciton effects? J. Chem. Phys. 133 (2010) 094701.

[72] L. Zanetti-Polzi, A. Amadei, R. Djemili, S. Durot, L. Schoepff, V. Heitz, B. Ventura, I. Daidone, Interpretation of experimental soret bands of porphyrins in flexible covalent cages and in their related Ag(I) fixed complexes, J. Phys. Chem. C 123 (2019) 1309413103.

[73] T.D. Lash, Modification of the porphyrin chromophore by ring fusion: identifying trends due to annelation of the porphyrin nucleus, J. Porphyrins Phthalocyanines 5 (2001) 267288.

[74] L. Chen, C. Zhang, L. Wu, K. Lv, K. Deng, T. Wu, A facile one-pot synthesis of biomimetic photocatalyst $\mathrm{Zn}(\mathrm{II})$-porphyrin-sensitized $3 \mathrm{D} \mathrm{TiO}_{2}$ hollow nanoboxes and synergistically enhanced visible-light degradation, Nanoscale Res. Lett. 13 (2018) 336.

[75] Q. Lu, Y. Zhang, S. Liu, Graphene quantum dots enhanced photocatalytic activity of zinc porphyrin toward the degradation of methylene blue under visible-light irradiation, J. Mater. Chem. A 3 (2015) 8552-8558.

[76] S. Gonuguntla, A. Tiwari, S. Madanaboina, G. Lingamallu, U. Pal, Revealing high hydrogen evolution activity in zinc porphyrin sensitized hierarchical porous $\mathrm{TiO} 2$ photocatalysts, Int. J. Hydrogen Energ. 45 (2020) 7508-7516. 
[77] S. Zhang, X. Zhang, H. Liu, Y. Lv, Z. Hou, Y. Song, Zn(II) porphyrin-based photocatalytic synthesis of $\mathrm{Cu}$ nanoparticles for electrochemical reduction of $\mathrm{CO} 2, \mathrm{~J}$. Porphyr. Phthalocya. 22 (2018) 406-412.

[78] Y. Kuramochi, Y. Fujisawa, A. Satake, Photocatalytic $\mathrm{CO}_{2}$ reduction mediated by electron transfer via the excited triplet state of $\mathrm{Zn}(\mathrm{II})$ porphyrin, J. Am. Chem. Soc. 142 (2020) 705-709.

[79] M. Bouzrati, M. Maier, C.P. Fik, C. Dietlin, F. Morlet-Savary, J.-P. Fouassier, J.E. Klee, J. Lalevée, A low migration phosphine to overcome the oxygen inhibition in new highperformance photoinitiating systems for photocurable dental type resins, Polym. Int. 66 (2017) 504-511.

[80] S.A. Buckler, Autoxidation of trialkyl phosphines. J. Am. Chem. Soc. 84 (1962) 30933097.

[81] C.S. Foote, J. Selverstone Valentine, A. Greenberg, J.F. Liebman, Active oxygen in chemistry, Blackie Academic \&. Professional, Chapman \& Hall, Wester Cleddens Road, Bishopbriggs, Glasgow G64 2NZ, 1st edition 1995, pp.55-58. 